\title{
Supplementary references.
}

$[1],[2],[3],[4],[5],[6],[7],[8],[9],[10],[11],[12],[13]$

1. Mohammadinejad P, Pourhamdi S, Abolhassani H, Mirminachi B, Havaei A, Masoom SN et al: Primary Antibody Deficiency in a Tertiary Referral Hospital: A 30-Year Experiment. J Investig Allergol Clin Immunol 2015, 25(6):416-425.

2. Garcia JM, Gamboa P, de la Calle A, Hernandez MD, Caballero MT, Garcia BE et al: Diagnosis and management of immunodeficiencies in adults by allergologists. J Investig Allergol Clin Immunol 2010, 20(3):185-194.

3. Ozkan H, Atlihan F, Genel F, Targan S, Gunvar T: IgA and/or IgG subclass deficiency in children with recurrent respiratory infections and its relationship with chronic pulmonary damage. J Investig Allergol Clin Immunol 2005, 15(1):69-74.

4. Yazdani R, Abolhassani H, Asgardoon M, Shaghaghi M, Modaresi M, Azizi G et al: Infectious and Noninfectious Pulmonary Complications in Patients With Primary Immunodeficiency Disorders. J Investig Allergol Clin Immunol 2017, 27(4):213-224.

5. Doherty TA, Broide DH: Group 2 innate lymphoid cells: new players in human allergic diseases. J Investig Allergol Clin Immunol 2015, 25(1):1-11; quiz 12p following 11.

6. Ercole LP, Malvezzi M, Boaretti AC, Utiyama SR, Rachid A: Analysis of lymphocyte subpopulations in systemic sclerosis. J Investig Allergol Clin Immunol 2003, 13(2):87-93.

7. Ohta A, Sitkovsky M: Role of G-protein-coupled adenosine receptors in downregulation of inflammation and protection from tissue damage. Nature 2001, 414(6866):916-920.

8. Mavilio D, Lombardo G, Benjamin J, Kim D, Follman D, Marcenaro E et al: Characterization of CD56-/CD16+ natural killer (NK) cells: a highly dysfunctional NK subset expanded in HIV-infected viremic individuals. Proceedings of the National Academy of Sciences of the United States of America 2005, 102(8):2886-2891.

9. Klose CS, Flach M, Mohle L, Rogell L, Hoyler T, Ebert K et al: Differentiation of type 1 ILCs from a common progenitor to all helper-like innate lymphoid cell lineages. Cell 2014, 157(2):340-356.

10. Fuchs A, Colonna M: Innate lymphoid cells in homeostasis, infection, chronic inflammation and tumors of the gastrointestinal tract. Curr Opin Gastroenterol 2013, 29(6):581-587.

11. Fuchs A, Vermi W, Lee JS, Lonardi S, Gilfillan S, Newberry RD et al: Intraepithelial type 1 innate lymphoid cells are a unique subset of IL-12- and IL-15-responsive IFN-gamma-producing cells. Immunity 2013, 38(4):769-781.

12. Yu J, Freud AG, Caligiuri MA: Location and cellular stages of natural killer cell development. Trends Immunol 2013, 34(12):573-582.

13. Shi FD, Ljunggren HG, La Cava A, Van Kaer L: Organ-specific features of natural killer cells. Nature reviews Immunology 2011, 11(10):658-671. 